Supporting Information

\title{
Surface Engineering of Mg electrode via New Additive to Reduce Overpotential
}

Zhen Meng, ${ }^{\dagger *}$ Zhenyou Li, ${ }^{\dagger}$ Liping Wang, ${ }^{\dagger}$ Thomas Diemant, ${ }^{\dagger}$ Dasari Bosubabu, ${ }^{\dagger}$ Yushu Tang, ${ }^{*}$ Romain Berthelot,,,$\|$ Zhirong Zhao-Karger, ${ }^{\dagger *}$ Maximilian Fichtner $\not+*$

${ }^{\dagger}$ Helmholtz Institute Ulm (HIU) Electrochemical Energy Storage, Helmholtzstraße 11, D-89081 Ulm, Germany

$\$$ Institute of Nanotechnology, Karlsruhe Institute of Technology (KIT), Hermann-von-Helmholtz-Platz 1, D-76344 Eggenstein-Leopoldshafen, Germany § ICGM, Univ. Montpellier, CNRS, ENSCM, 34095, Montpellier, France

"| Réseau sur le Stockage Électrochimique de l'Énergie (RS2E), CNRS, 80039, Amiens, France

*Corresponding authors:

E-mail:

zhen.meng@partner.kit.edu (Zhen Meng)

zhirong.zhao-karger@kit.edu (Zhirong Zhao-Karger)

maximilian.fichtner@kit.edu (Maximilian Fichtner) 

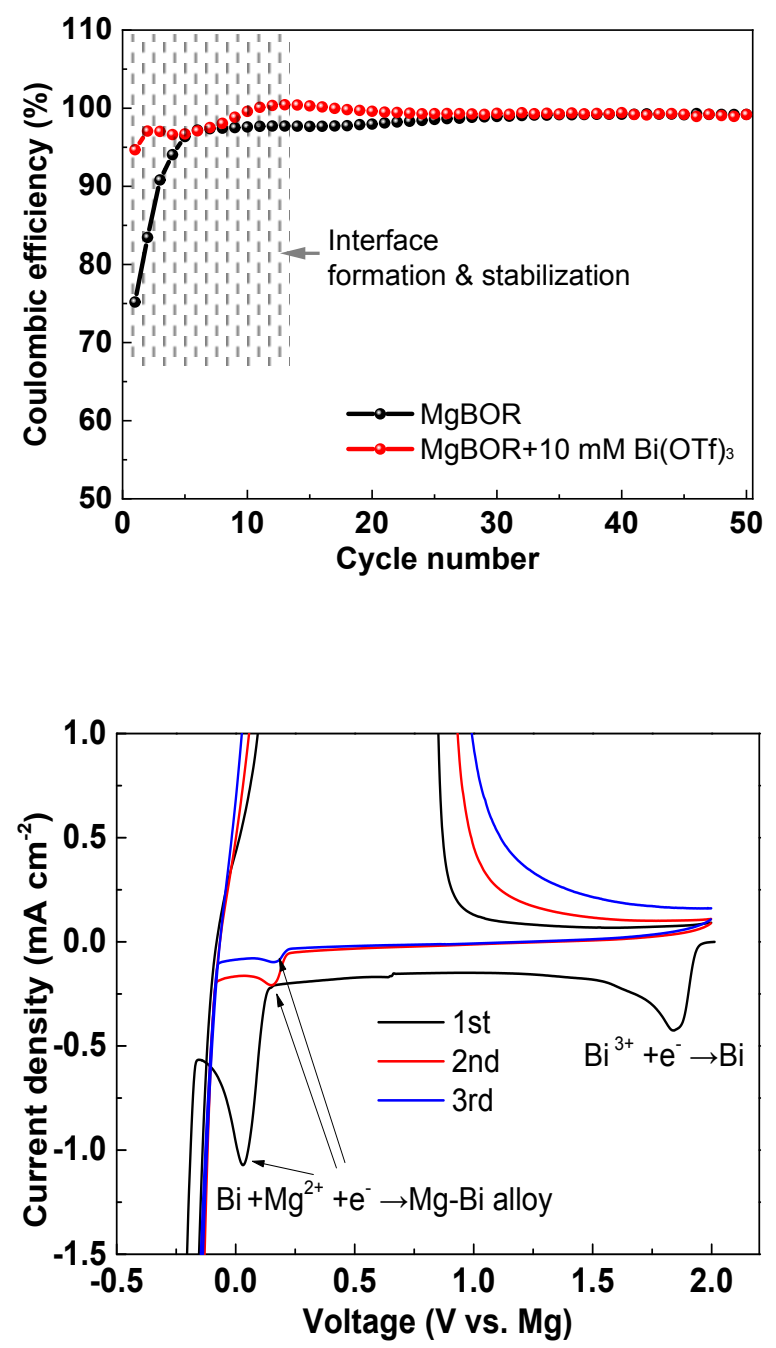

Figure S1. Top: comparison of the Coulombic efficiencies of $\mathrm{Mg}$ plating/stripping in the MgBOR/DME electrolytes with and without $10 \mathrm{mM} \mathrm{Bi(OTf})_{3}$ additive. Buttom: Magnified view of the first three $\mathrm{CV}$ curves of the electrolyte with $\mathrm{Bi}(\mathrm{OTf})_{3}$ additive.

The initial cycles are related to the active interface formation. During this period, the electrolyte and the electrolyte/electrode interface are erratic, which could be influenced by many factors such as the roughness of the stainless steel current collector and the impurities in the electrolyte. 


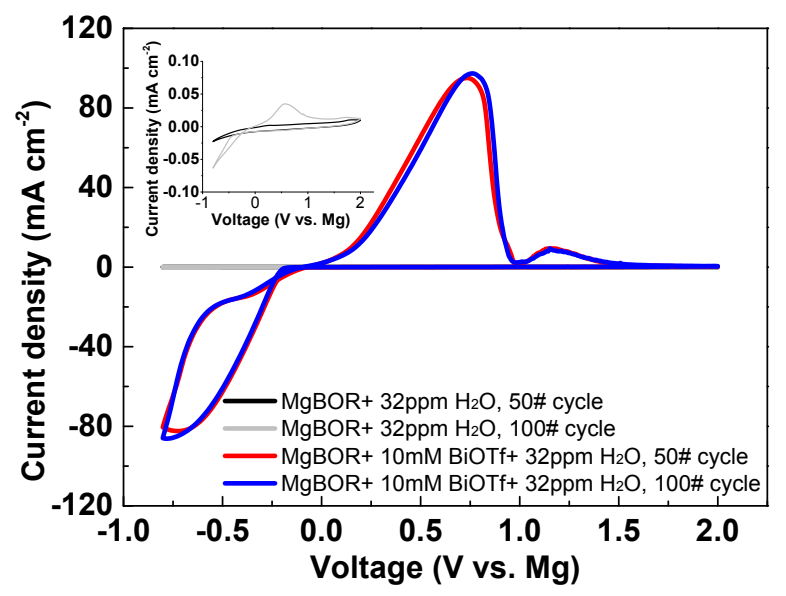

Figure $\mathrm{S} 2 . \mathrm{CV}$ curves of the $50^{\text {th }}$ and $100^{\text {th }}$ cycle with $\mathrm{MgBOR} / \mathrm{DME}+32 \mathrm{ppm}_{2} \mathrm{O}$ electrolyte with and without $10 \mathrm{mM} \mathrm{Bi(OTf)})_{3}$. Inset shows a magnified view of the $\mathrm{CV}$ curves of the MgBOR/DME $+32 \mathrm{ppm} \mathrm{H}_{2} \mathrm{O}$ electrolyte. 

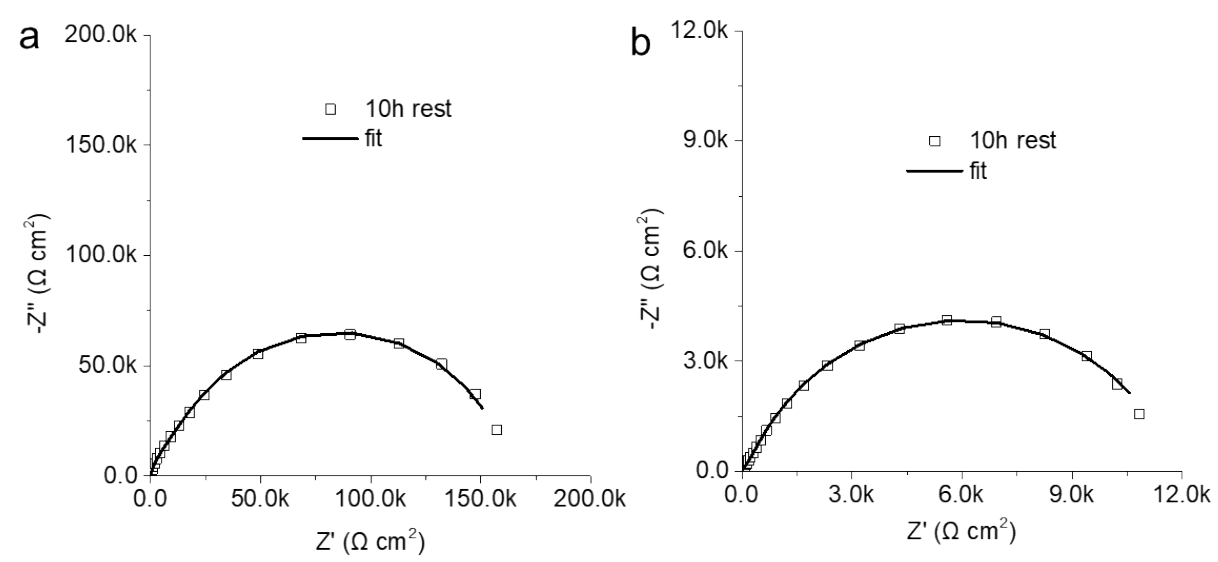

Figure S3. Impedance fitting results of Figure 3 after $10 \mathrm{~h}$ restmea. (a) Blank MgBOR electrolyte, (b) MgBOR/10 mM Bi(OTf) $)_{3}$ electrolyte.

Table S1. Data of impedance fitting obtained from Figure S3 and the corresponding equivalent circuit.

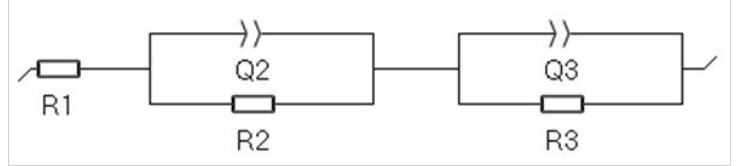

\begin{tabular}{|l|l|l|}
\hline & Without Bi(OTf) & With Bi(OTf) \\
\hline R1 (Ohm) & 3.668 & 4.016 \\
\hline R2(Ohm) & 11820 & 199.6 \\
\hline R3(Ohm) & 196247 & 14926 \\
\hline
\end{tabular}



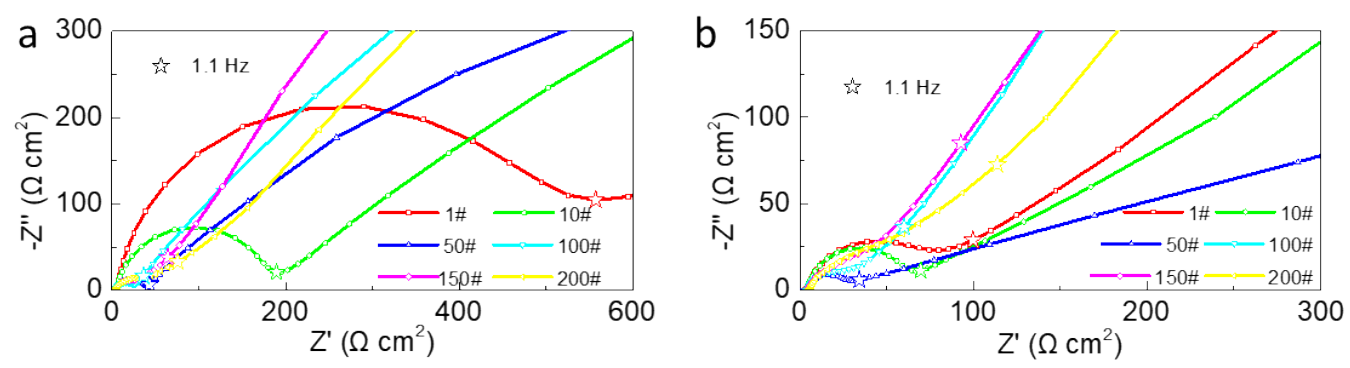

Figure S4. Impedance measurements of $\mathrm{Mg} / \mathrm{Mg}$ cells after different cycles, (a) blank MgBOR/DME electrolyte, (b) MgBOR/DME electrolyte with $10 \mathrm{mM}$ of Bi(OTf) 3 . 


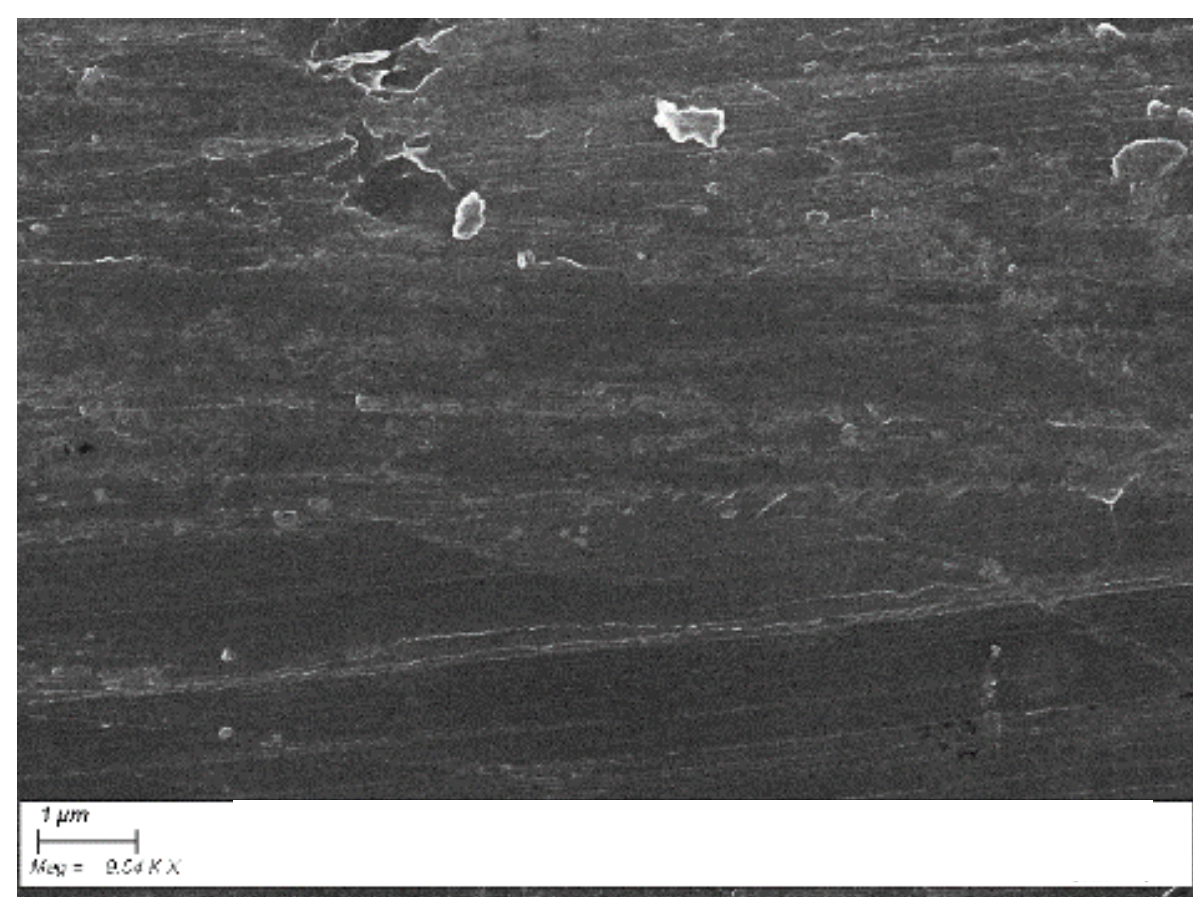

Figure S5. SEM image of the pure Mg. 


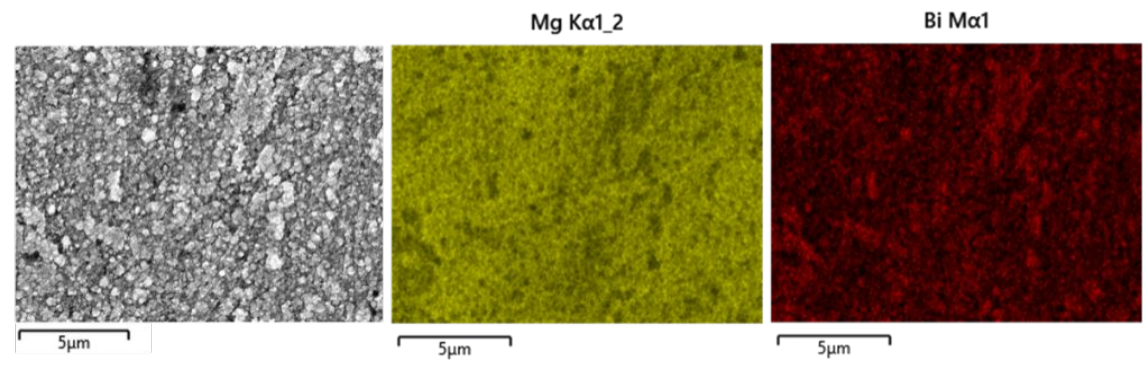

Figure S6. SEM image and energy-dispersive X-ray (EDX) elemental mapping of MgBi interface. 


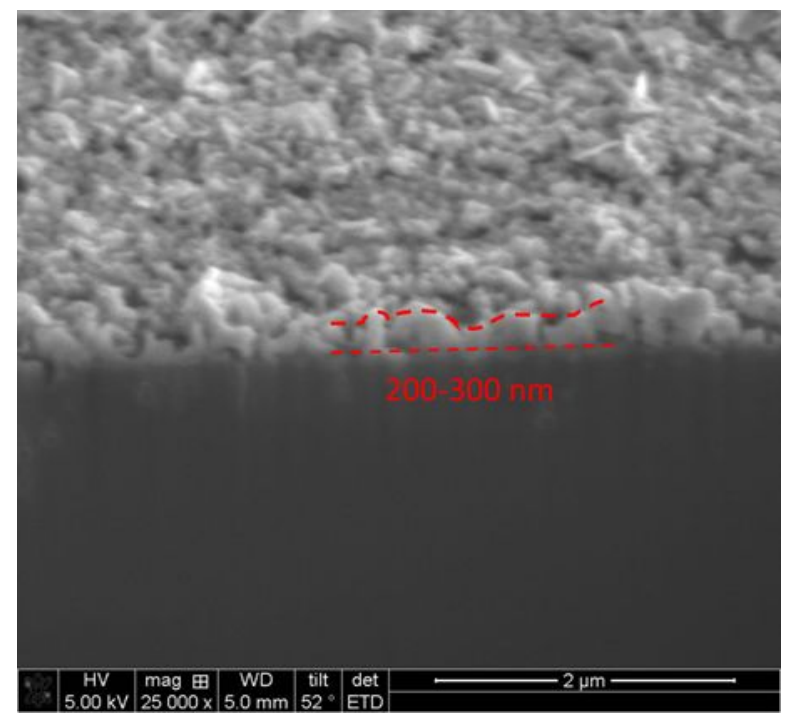

Figure S7. Cross-section SEM image of Mg-Bi interface. 


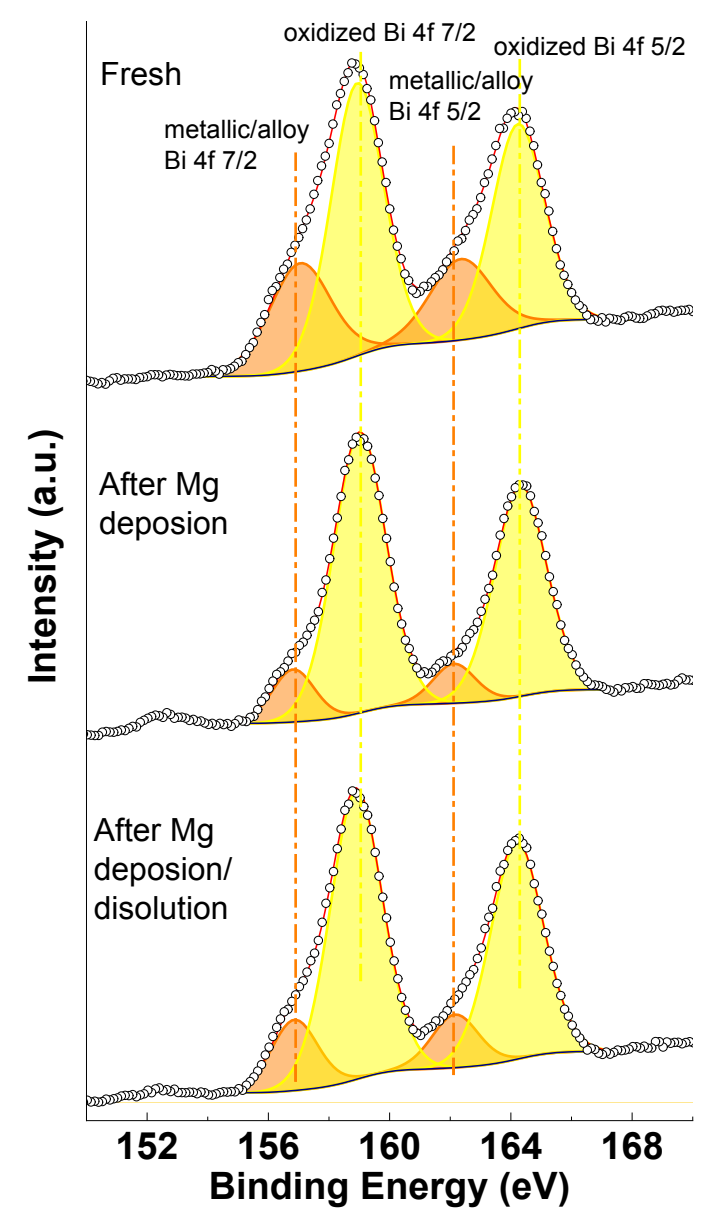

Figure S8. XPS spectra of Mg electrodes at different charge state after dipping / cycling in $\mathrm{MgBOR} / \mathrm{DME}+10 \mathrm{mM} \mathrm{Bi}(\mathrm{OTf})_{3}$ electrolyte. Top: fresh sample; middle: after 1 mAh $\mathrm{cm}^{-2} \mathrm{Mg}$ deposition (10 h at $\left.0.1 \mathrm{~mA} \mathrm{~cm}^{-2}\right)$; bottom: after $1 \mathrm{mAh} \mathrm{cm}^{-2}$ of $\mathrm{Mg}$

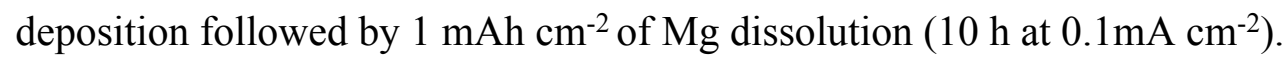



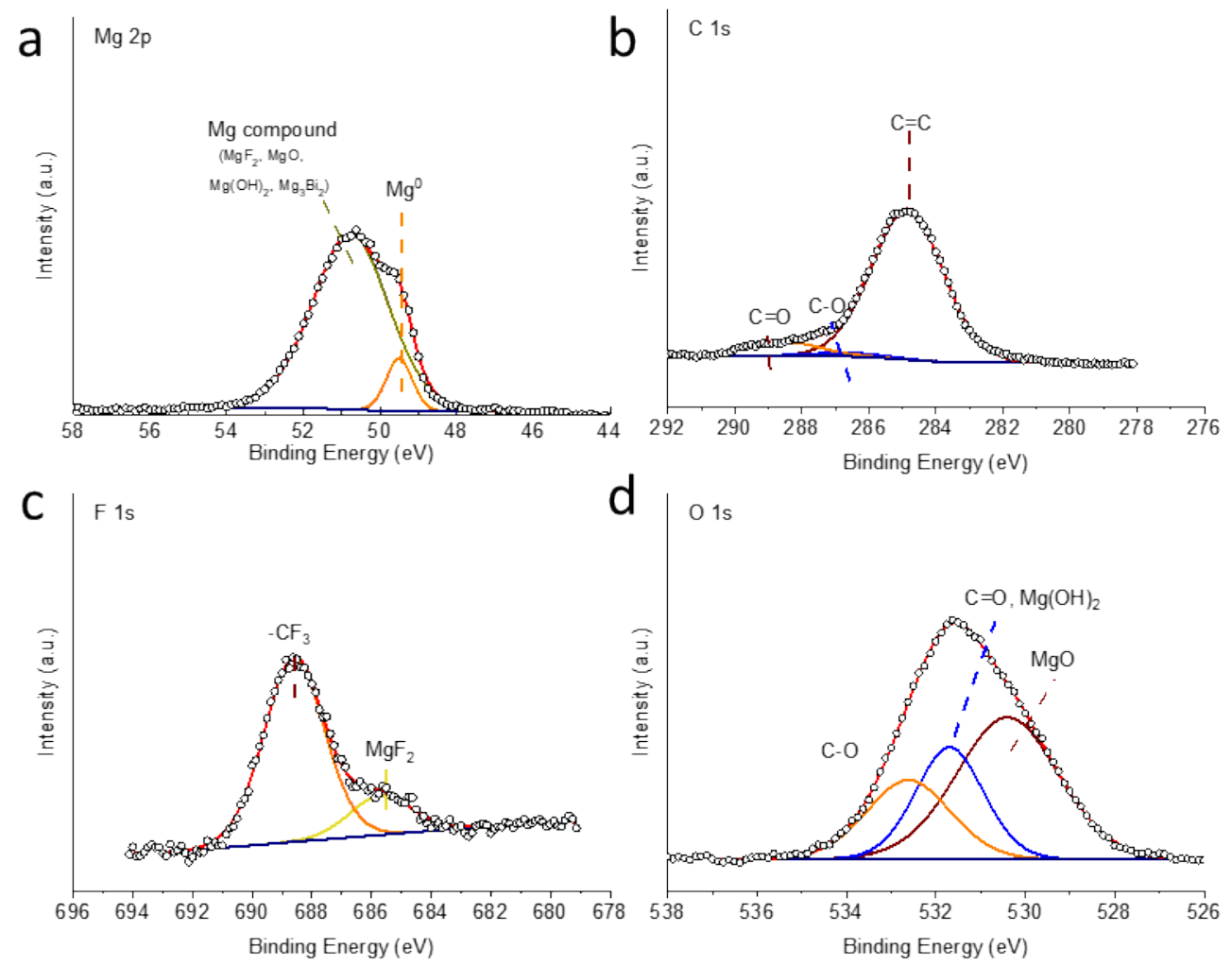

Figure S9. XPS spectra of the Mg-Bi interface. 


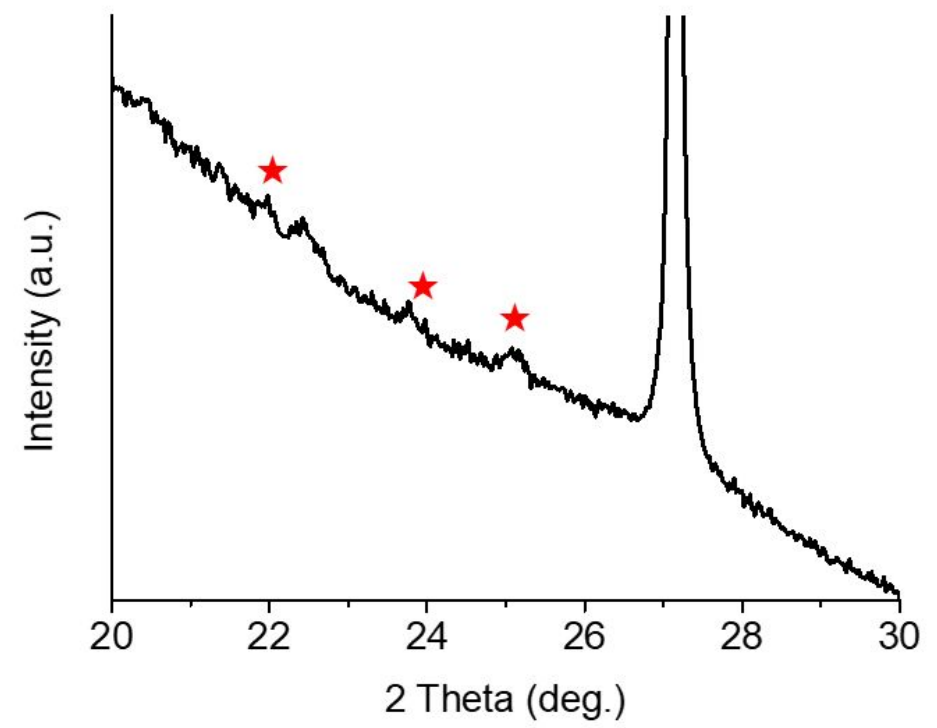

Figure S10. Magnified view between 20 and $30^{\circ}$ of the XRD pattern of a Mg-Bi sample. 

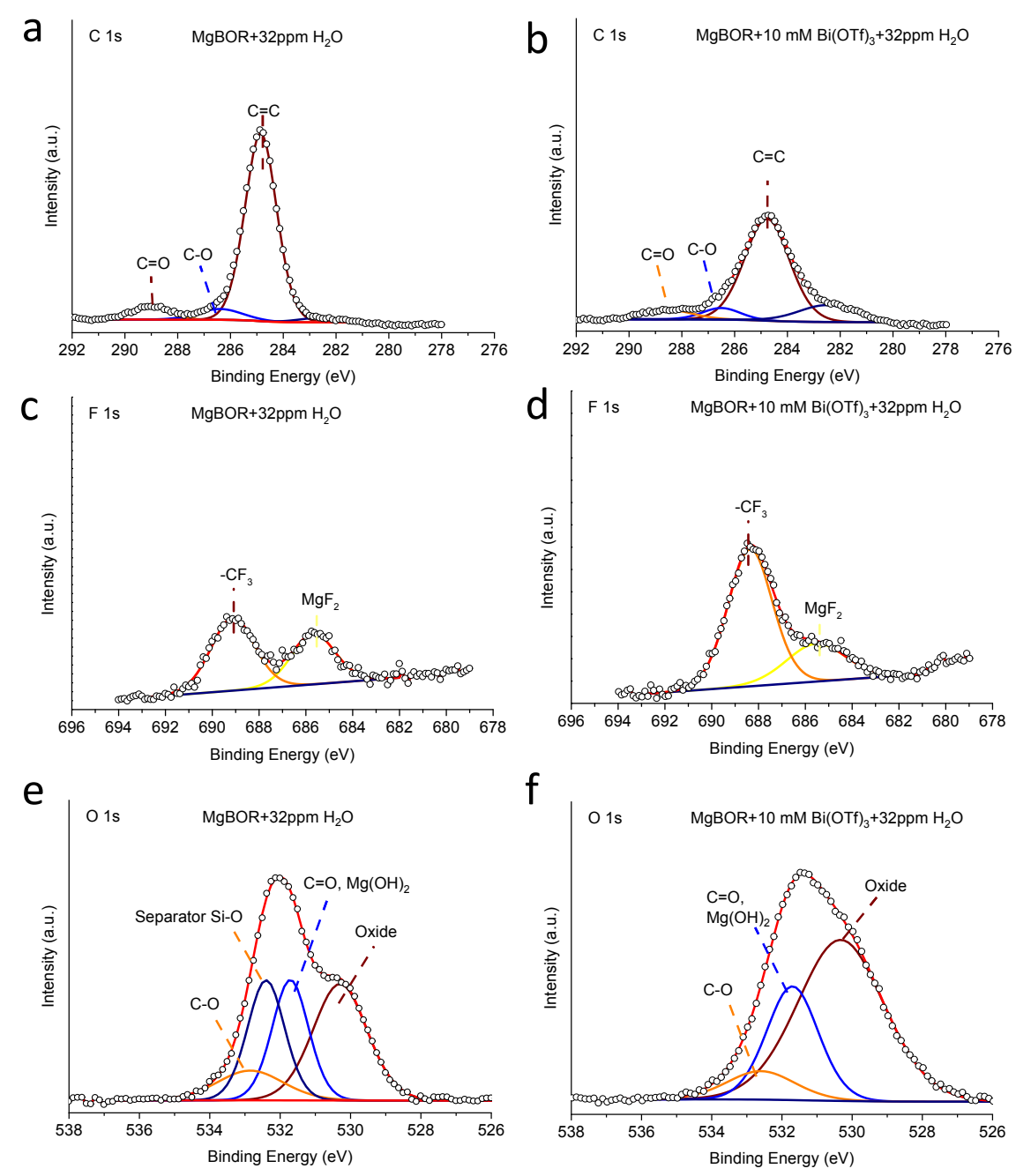

Figure S11. XPS spectra of the Mg electrode after exposure to different electrolytes for 5h. (a, c, e) MgBOR/DME+32 ppm of $\mathrm{H}_{2} \mathrm{O}$ electrolyte, (b, d, f) MgBOR/DME+10 $\mathrm{mM} \mathrm{Bi(OTf})_{3}+32 \mathrm{ppm}$ of $\mathrm{H}_{2} \mathrm{O}$ electrolyte.

Four peaks were introduced for the peak fit of the spectra in the $\mathrm{C} 1 \mathrm{~s}$ range. The main peak at $284.8 \mathrm{eV}$ can be assigned to $\mathrm{C}-\mathrm{C} / \mathrm{C}-\mathrm{H}$ species; further peaks were introduced at $286.5 \mathrm{eV}(\mathrm{C}-\mathrm{O}), 288.5 \mathrm{eV}(\mathrm{C}=\mathrm{O})$ and $282.5 \mathrm{eV}$ (carbide species, most probably formed after direct contact with the $\mathrm{Mg}$ surface). The spectra in the $\mathrm{O} 1 \mathrm{~s}$ range were fitted in general with three peaks, which are attributed to metal oxides $(530.3 \mathrm{eV}), \mathrm{Mg}(\mathrm{OH})_{2}$ together with $\mathrm{C}=\mathrm{O}$ groups $(531.7 \mathrm{eV})$ and $\mathrm{C}-\mathrm{O}$ groups $(532.7 \mathrm{eV})$. It should be noted 
that an additional peak at $532.4 \mathrm{eV}$ had to be added for the $\mathrm{Mg}$ samples, since the $\mathrm{Si} 2 \mathrm{p}$ and $\mathrm{Si} 2 \mathrm{~s}$ peaks of oxidized Si could be detected in this case, which is due to the silicabased separator. The intensity of this feature was calculated based on the intensity of the Si 2s peak taking into account the expected stoichiometry and the sensitivity factors. The F 1s detail spectra were fitted with two peaks, corresponding to $\mathrm{MgF}_{2}(685.5 \mathrm{eV})$ and $-\mathrm{CF}_{3}$ groups of the electrolyte $(\sim 688.5 \mathrm{eV})$. 


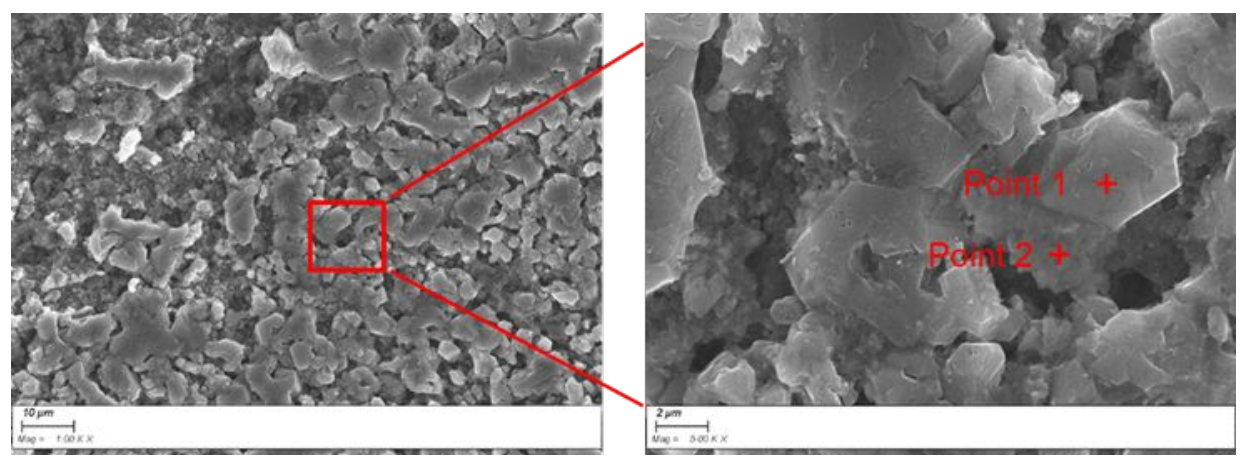

Figure S12. SEM images of the Mg electrode surface after 50 cycles at $1 \mathrm{~mA} \mathrm{~cm}^{-2}$ in MgBOR/DME electrolyte with $\mathrm{Bi}(\mathrm{OTf})_{3}$ additive. Point 1 might be a Mg crystallite (cf. low Bi content in Table S2), while Point 2 is the Mg-Bi composite.

Table S2. Element analysis of Figure S10.

\begin{tabular}{|l|l|l|}
\hline & Point 1 & Point 2 \\
\hline Element & Atomic \% & Atomic \% \\
\hline C & 13.57 & 20.88 \\
\hline O & 6.92 & 21.35 \\
\hline F & 0.91 & 1.48 \\
\hline Mg & 78.52 & 53.86 \\
\hline Bi & 0.08 & 2.43 \\
\hline Total & 100 & 100 \\
\hline
\end{tabular}



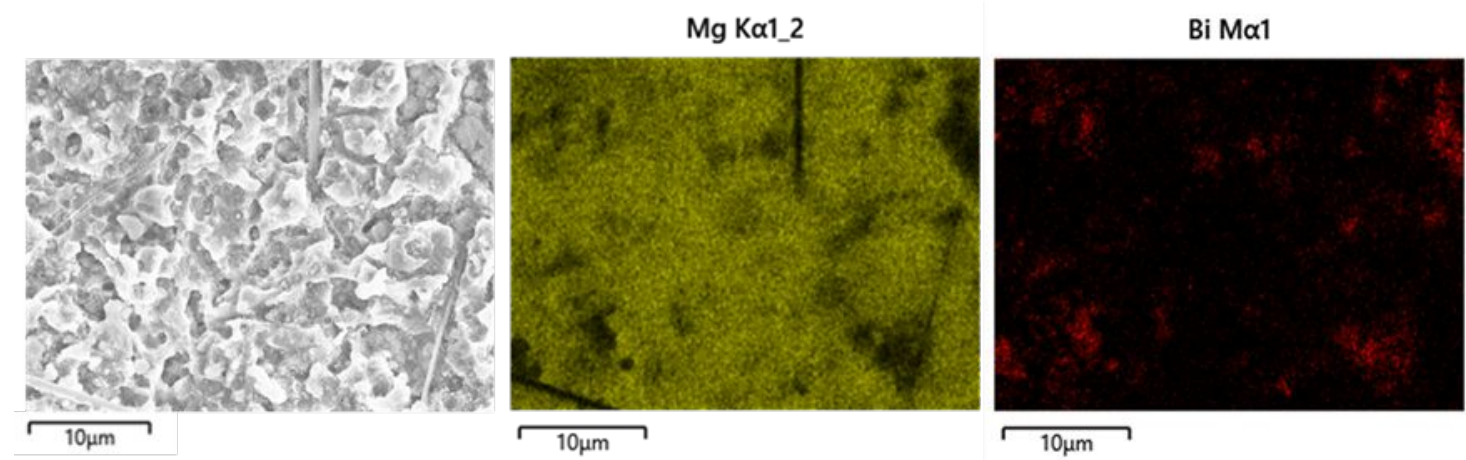

Figure S13. SEM image and energy-dispersive X-ray (EDX) elemental mapping of MgBi after 100 cycles at $1 \mathrm{~mA} \mathrm{~cm} \mathrm{~cm}^{-2}$.

Higher Mg-Bi coverage on the surface means more active sites for Mg plating/stripping, which would lower the overpotential and increase the kinetics. Instead, incomplete surface coverage by $\mathrm{Bi} / \mathrm{Mg}-\mathrm{Bi}$ alloy could lead to less active sites, increasing the actual current density on these active sites, which would increase the overpotential and speed up the degradation of the beneficial layer. 

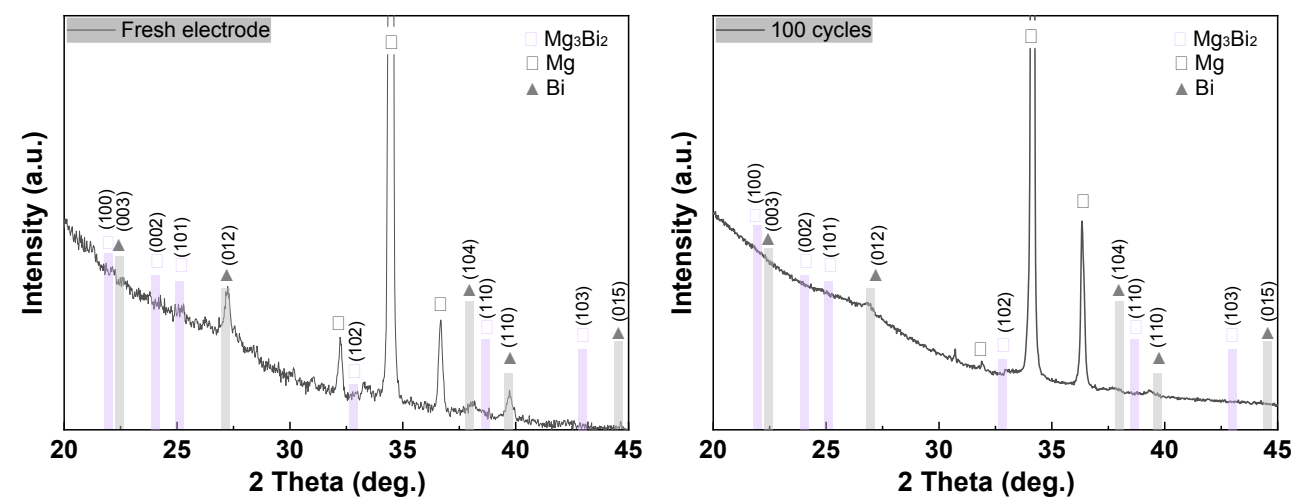

Figure S14. XRD of Mg electrode. Left: contact with $50 \mu \mathrm{L} \mathrm{MgBOR/DME}+10 \mathrm{mM}$ $\mathrm{Bi}(\mathrm{OTf})_{3}$ additive electrolyte. Right: after 100 cycles in a $\mathrm{Mg}-\mathrm{Mg}$ cell with $50 \mu \mathrm{L}$ $\mathrm{MgBOR} / \mathrm{DME}+10 \mathrm{mM} \mathrm{Bi}(\mathrm{OTf})_{3}$ additive.

After 100 cycles, the $\mathrm{Mg}_{3} \mathrm{Bi}_{2}$ was undetectable, which maybe caused by two reasons:

1) the electrochemical grinding reduced the particle size and/or the crystallinity of $\mathrm{Mg}_{3} \mathrm{Bi}_{2},{ }^{1}$ 2) the $\mathrm{Mg}_{3} \mathrm{Bi}_{2}$ was covered by $\mathrm{Mg}$. 

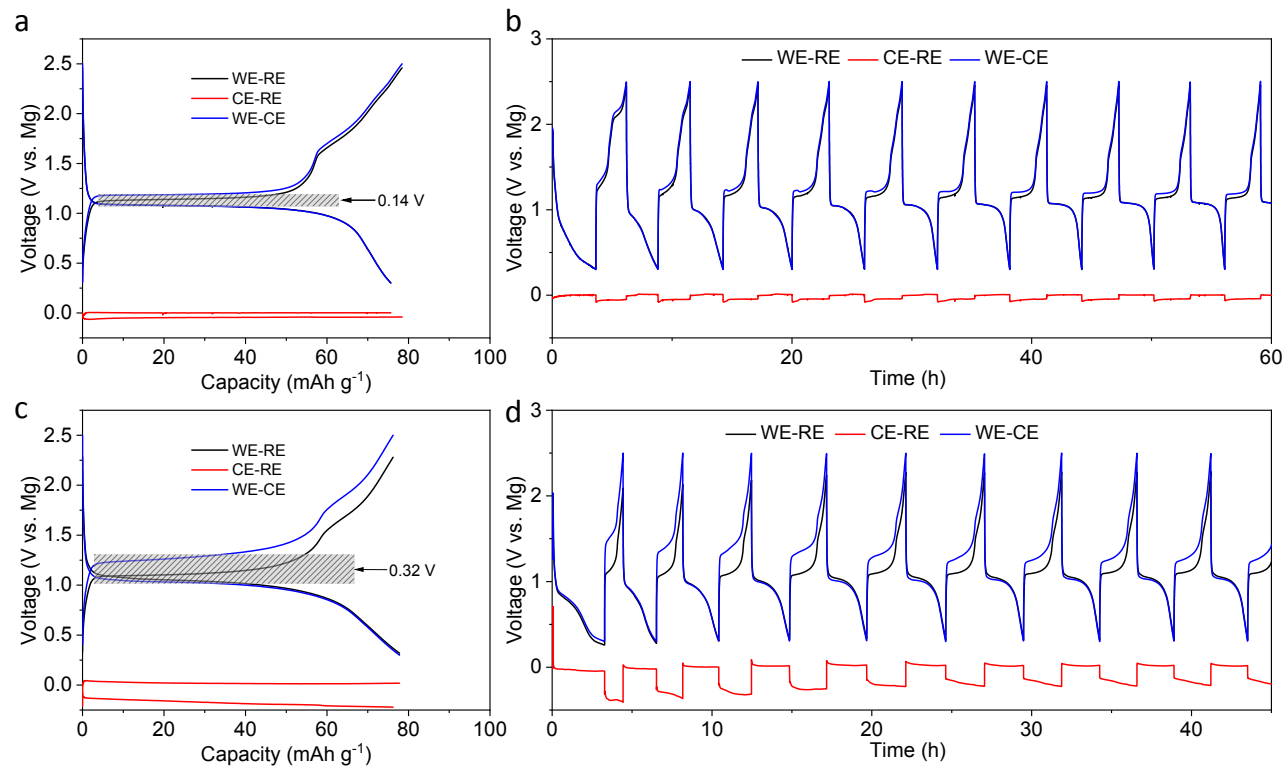

Figure S15. $(a, b)$ 10th cycle voltage profile (a) and the first 10 cycles voltage profiles (b) of the $\mathrm{Mo}_{6} \mathrm{~S}_{8}$ countered with $\mathrm{Mg}$-Bi anode. (c,d) 10th cycle voltage profile (c) and the first 10 cycles voltage profiles (d) of the $\mathrm{Mo}_{6} \mathrm{~S}_{8}$ countered with $\mathrm{Mg}$ anode. The current density is $26 \mathrm{~mA} \mathrm{~g}^{-1} \mathrm{Mos} 8$. 

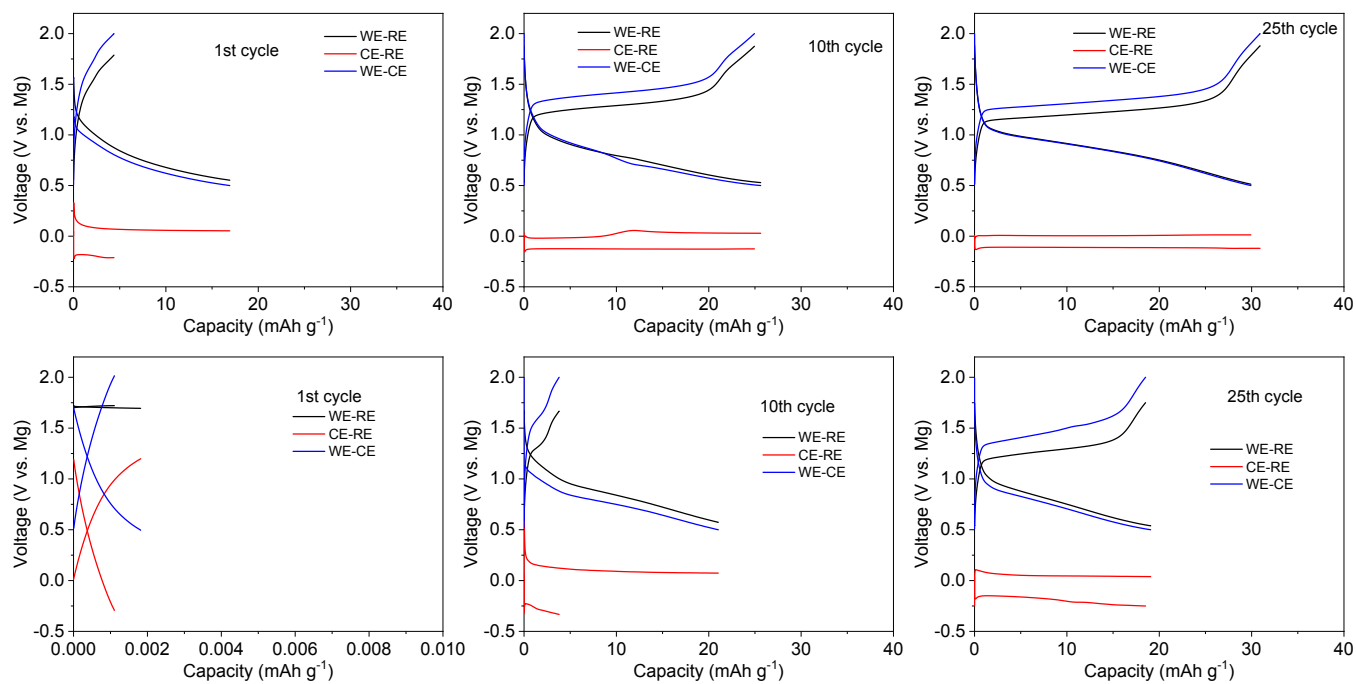

Figure S16. Voltage profile of the cell with $\mathrm{Mo}_{6} \mathrm{~S}_{8}$ cathode and $\mathrm{Mg}$-Bi anode (the 3 figures above) and $\mathrm{Mg}$ anode (the 3 figures below) in 3-electrode batteries. The current density is $50 \mathrm{~mA} \mathrm{~g}^{-1} \mathrm{MorS}_{8}$.

Given that the large $\mathrm{Mg}$ stripping/plating overpotential in a full $\mathrm{Mg}$ battery system will undoubtedly impact the overall electrochemical performance during its operation, three-electrode cells with chevrel phase $\mathrm{Mo}_{6} \mathrm{~S}_{8}$ cathodes were assembled. A Mg ring was employed as reference electrode (RE). To eliminate the reaction between $\mathrm{Mg}$ reference and $\mathrm{Bi}(\mathrm{OTf})_{3}$ additive, pure $\mathrm{MgBOR} / \mathrm{DME}$ electrolyte was used, coupled with $\mathrm{Mg}-\mathrm{Bi}$ and $\mathrm{Mg}$ anodes, respectively. During the battery operation, we found that not only the $\mathrm{Mg}$ anode but also the $\mathrm{Mo}_{6} \mathrm{~S}_{8}$ cathode suffered from an "activation" process. This activation process became longer when higher current density was used. However, the mechanism of this "cathode activation" is beyond the scope of this article. Figure S12 shows that the cell with $\mathrm{Mg}$ as anode reached to the cut-off voltage rapidly with almost no discharge/charge capacity in the first cycle. It demonstrates clearly that the initial large overpotential originated from the $\mathrm{Mg}$ anode side and it is plausible that 
it corresponded to the large initial voltage spike in Figure 3 and dominated the fast voltage change of the $\mathrm{Mo}_{6} \mathrm{~S}_{8}-\mathrm{Mg}$ battery, leading to almost no capacity. This phenomenon proceeds for 9 cycles (Figure S12, the 3 figures below). Afterwards, the full cell performance gradually improved, accompanied by Mg plating/stripping started and enhanced. With Mg-Bi as the anode, however, the cell operated normally with the anode overpotential of roughly $0.4 \mathrm{~V}$ in the first cycle. This proved unequivocally that the anode/electrolyte conditioning profoundly affects the performance of the entire cell. 


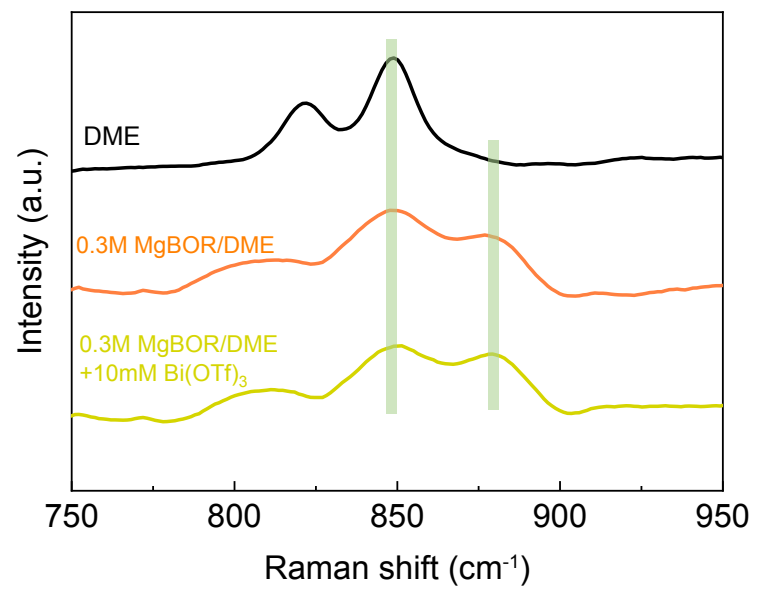

Figure S17. Raman spectra of the DME, MgBOR/DME electrolyte and MgBOR/DME electrolyte with additive. 


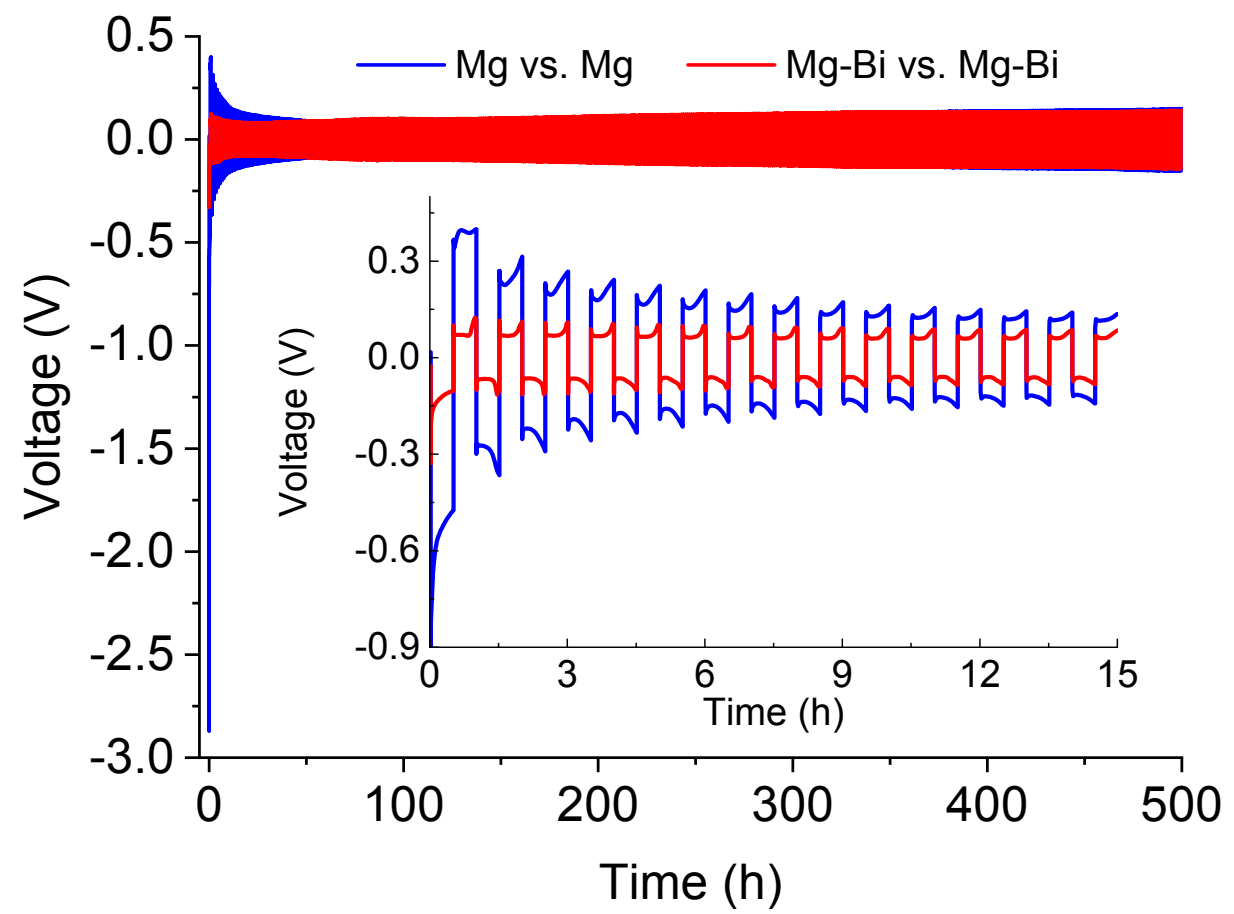

Figure $\mathrm{S} 18 . \mathrm{Mg}$ plating/stripping performance of the symmetric $\mathrm{Mg}-\mathrm{Bi} / \mathrm{Mg}-\mathrm{Bi}$ and $\mathrm{Mg} / \mathrm{Mg}$ cells with $0.3 \mathrm{M} \mathrm{MgBOR} / \mathrm{DME}$ electrolyte at $1 \mathrm{~mA} / \mathrm{cm}^{2}$ (inset is the performance of the first 15 hours). 


\section{Reference}

(1) Murgia, F.; Stievano, L.; Monconduit, L.; Berthelot, R. Insight into the Electrochemical Behavior of Micrometric $\mathrm{Bi}$ and $\mathrm{Mg}_{3} \mathrm{Bi}_{2}$ as High Performance Negative Electrodes for Mg Batteries. J. Mater. Chem. A 2015, 3, 16478-16485. 